\title{
David Oliver: Let's argue about statistics
}

\author{
David Oliver consultant in geriatrics and acute general medicine
}

Berkshire

In his recent speech to the Conservative Party conference the health secretary, Jeremy Hunt, used statistics enthusiastically. ${ }^{1}$ I counted at least 27 times that he mentioned numerical data. And he made several more assertions about numbers, such as, "Safer care doesn't cost more; it costs less." Not bad for a speech of 23 minutes. ${ }^{2}$

He used statistics to take credit on behalf of his government for purported greater NHS activity. Then he used data to highlight poor or inconsistent NHS performance to justify reforms. And he cited data in support of his commitment to an uncosted "seven day NHS" and changes to doctors' contracts.

But statistics about the huge funding and workforce gaps in our health and social care system and their adverse impact on performance were understandably absent. So were data about services defunded and cut since 2010. But that's OK: "Just writing a cheque doesn't raise standards," Hunt asserted confidently.

Hunt praised doctors "using hard data" to improve services and announced publication of "Ofsted-style ratings" for performance of cancer services. ${ }^{3}$ He promised that hospitals would publish their "preventable mortality estimates." This all seems consistent with his previous promises to make transparent use of intelligent data.

Having used selective and contestable statistics to take credit for stated successes, he then shifted the blame for performance gaps away from the Treasury and Department of Health to local clinicians and managers; and, styling himself as the true champion of patient safety, he said something deserving of its very own paragraph:

"So I say ... to the BMA and to junior doctors, let's not argue about statistics."

Let's get this straight, Mr Hunt. Academic doctors, statisticians, and health service researchers have produced most of the data that you're using selectively to support your public relations agenda. Yet you're telling them that they shouldn't argue over data, contradicting the principles of their training and the culture of academic peer review.
Perhaps we shouldn't be surprised. Hunt ignored the cautions of statistically literate analysts in pushing an uncosted model for seven day services

Perhaps we shouldn't be surprised. You ignored the cautions of statistically literate analysts at the Department of Health in the rush to push an uncosted model for seven day services. ${ }^{4}$ Then you refused to heed expert challenges to your assertion, which you repeated at the conference, of "eight independent studies confirming a mortality rate up to $15 \%$ higher for those admitted to the weekend."

I know that Mr Justice Green upheld your ministerial right to interpret such studies and their policy implications. ${ }^{5}$ But "let's not argue about statistics" conveniently invalidates all objections, and there's no ministerial monopoly on the use or interpretation of peer reviewed data.

The day that trained professionals stop disputing selective use of data by government, lobbyists, think tanks, or the media for their own political and public relations ends will be a nail in democracy's coffin.

Competing interests: See www.bmj.com/about-bmj/freelancecontributors/david-oliver.

Provenance and peer review: Commissioned; not externally peer reviewed.

1 Spectator. Full text: Jeremy Hunt's Tory party conference speech. 4 Oct 2016. http://blogs. spectator.co.uk/2016/10/full-text-jeremy-hunts-tory-party-conference-speech/.

2 Hunt J. Speech to Conservative Party conference 2016. YouTube 2016 Oct 4. https:// www.youtube.com/watch?v=KHEz1WPMLLw.

3 England NHS. New cancer ratings published. 4 Oct 2016. https://www.england.nhs.uk/ cancer/2016/10/04/cancer-ratings/.

4 Campbell D. Secret documents reveal official concerns over "seven-day NHS" plans. Guardian 2016 Aug 22. https://www.theguardian.com/society/2016/aug/22/secretdocuments-reveal-official-concerns-over-seven-day-nhs-plans.

5 Triggle N. Junior doctors lose High Court case. BBC News 2016 Sep 28. www.bbc.co.uk news/health-37481677.

Published by the BMJ Publishing Group Limited. For permission to use (where not already granted under a licence) please go to http://group.bmj.com/group/rights-licensing/ permissions 